\title{
Time to move on from the euthanasia debate
}

Previously published at www.cmaj.ca

I

$\mathrm{n}$ living, suffering and dying, most of us want to extend the first, minimize the second and pass swiftly through the third.

However, at the prospect of death, two views collide. The first holds that the length of our lives is in the hands of a higher power and that death can only be accepted as and when it comes. The second is that we have full autonomy over how we live and that we can choose when and how we die. We certainly live in a time when we have more potential control over our dying. But when it's needed, the discussion about that control - by whom and how much - seems to lead to enmeshed families at the bedside or to entrenched positions in public discourse.

Such contrasting ideas are usually superseded by a new and different form of understanding, rendering the impasse irrelevant. In Canada, as debate resumes in Quebec and in Parliament about a physician's role in caring for a patient's end of life, we need to reach that understanding - the sooner the better.

The way forward will require honest engagement and dialogue at a societal level. An important first step is defining the words we use.

The end-of-life debate seems burdened by confusion over the word euthanasia. ${ }^{1,2}$ Opposing sides use it to further their ideological views: murder versus mercy; the right to live versus the right to die with dignity; selfishness versus compassion.

Deliberately crafted in 1646 from the Greek eu (well or easy) and thanatos (death), the word euthanasia was first intended to mean a gentle and easy death. ${ }^{2}$ By 1742 , a nuance was introduced referring to the means of bringing about such a death and, in 1859 , to the action of inducing such a death. Modern dictionaries have various definitions, but all of them imply an intentional action to bring about death in someone who is suffering.

But this broad meaning has inadvertently enveloped actions that also involve the relief of symptoms in dying people. For example, withholding food and hydration, mechanical ventilation or cardiopulmonary resuscitation can be appropriate palliative measures. Also, administering enough narcotics to relieve pain in patients with cancer and adding enough sedation to enable comfort and minimize agitation is appropriate and compassionate care, even when the amounts required increase the probability of death.

It can be argued that, in such circumstances, death becomes an acceptable side effect of effective palliation. But it is not euthanasia.

Nevertheless, it is likely that many physicians who respond to surveys about euthanasia have such medical care in mind.
Indeed, in Quebec last year, $81 \%$ of medical specialists surveyed said they had seen "euthanasia" practised, and $48 \%$ said that palliative sedation "can be likened to a form of euthanasia."

That emollient word euthanasia, stitched together from classical Greek, once expressed a concept that has now become frayed and torn. It mixes ideas and values that confound the debate about dying. It is time to discard it.

It can start with us. As Kuiper and colleagues ${ }^{2}$ and others have suggested, physicians can stop using the word euthanasia to describe the actions we might take to help dying patients and stop using such value-laden terms as starve and kill to explain those medical actions. Instead, we can clearly and dispassionately name and define each action as well as its possible repercussions.

By using each term purposefully, patients, their families and society in general can begin to recognize the differences, and we can start to create a framework for considering the risks, benefits and moral worth of each action.

Similarly, the term we choose to use to discuss a deliberate, death-inducing intervention must honestly represent both its action and its intention. Assisted suicide, for example, clearly refers to an instance in which a person helps someone take his or her own life.

As physicians, we should promote honest dialogue; help define actions and terms; avoid further polarization of this important debate with our own values and ideologies; and help educate the public to enable engagement in this very important societal issue. Then "euthanasia" can experience its own gentle death.

\section{Ken Flegel MDCM MSc}

Senior Associate Editor

Paul C. Hébert MD MHSc

Editor-in-Chief

CMAJ

Editorial advisory team: Noni MacDonald MD MSc,

Matthew B. Stanbrook MD PhD and Joan Ramsay BA

Competing interests: See www.cmaj.ca/misc/edboard.shtml

CMAJ 2010. DOI:10.1503/cmaj.100338

\section{REFERENCES}

1. Materstvedt LJ, Clark D, Ellershaw J, et al. Euthanasia and physician-assisted suicide: a view from an EAPC Ethics Task Force. Palliat Med 2003;17: 97-101.

2. Kuiper MA, Whetstine LM, Holmes JL, et al. Euthanasia: a word no longer to be used or abused [letter]. Intensive Care Med 2007;33:549-50.

3. Fédération des médecins spécialistes du Québec. Euthanasia: the key points of the FMSQ Survey. Available: www.fmsq.org/e/centredepresse/communiques/coms /20091013.html (accessed 2010 Feb. 25). 